\title{
HUMAN RESOURCE MANAGEMENT AS A SUBSTITUTE FOR TRADE UNIONS IN BRITISH WORKPLACES
}

\author{
STEPHEN MACHIN and STEPHEN WOOD*
}

\begin{abstract}
The authors use British workplace data for 1980-98 to examine whether increased human resource management (HRM) practices coincided with union decline, consistent with the hypothesis that such practices act as a substitute for unionization. Two initial analyses show no important differences between union and non-union sectors or between newer workplaces (which are likelier to be non-union) and older ones in the pattern of HRM practices over time; and the study's longitudinal analysis picks up no evidence of faster union decline in workplaces or industries that adopted HRM practices than in those that did not. Not only is the hypothesized substitution effect thus not supported, but the authors even uncover some evidence of a complementarity between unions and HRM practices. The authors conclude that increased use of HRM practices is probably not an important factor underpinning union decline in Britain.
\end{abstract}

$\mathbf{T}$ he decline of trade unionism has been a feature of many countries in recent years (Verma et al. 2002) and the subject of a large body of research. Union decline has been especially strong in Britain over the past 25 years. In the late 1970 s over 13 million people-or around $58 \%$ of workers-were trade union members, and wages for over $70 \%$ of workers were set by collective bargaining. Since reaching its peak in 1979, unionization (however measured) has fallen year after year, so that by 2004 less

\footnotetext{
*Stephen Machin is Professor of Economics, University College London, and Research Director of the Centre for Economic Performance, London School of Economics; Stephen Wood is Professor of Work Psychology, Deputy Director of the Institute of Work Psychology, and Co-Director of the ESRC Centre for Organisation and Innovation, University of Sheffield, and Associate of the Centre for Economic Performance, London School of Economics. This research is part of a joint project between the Leverhulme Foundation-funded research on the Future of Trade
}

than $30 \%$ of workers were members of a trade union.

Coinciding with the decline in trade unionism has been an increase in the use of human relations practices and new forms of work organization. These are often subsumed under labels such as high-involvement, high-commitment, and high-performance management, or simply human resource management. For convenience we shall follow Fiorito (2001), a major U.S. writer on union substitution, and use the term human resource management (HRM).

\footnotetext{
Unionism in Modern Britain and the ESRC Centre for Innovation and Organisation (Grant Number RA013461). The empirical research is based on data from the Workplace Industrial/Employee Relations series, which is deposited at the Data Archive at the University of Essex, U.K. (http://www.esrc.ac.uk). The authors thank Alex Bryson, Peter Cappelli, and participants at the Labor seminar at Wharton Business School for comments, and Alison Geldart for editorial assistance.
} 
The increased adoption of HRM practices has been presented, particularly in the prescriptive management literature, as providing the basis for a new win-win relationship between workers and managers. It is argued that they offer management the prospect of improved performance while improving workers' job satisfaction, security, and perhaps pay and benefits.

The increasing adoption of the term highperformance methods, even in the industrial relations literature, implies an acceptance of the validity of this chain of argument. If it is indeed the case that these modern HRM methods enhance workers' satisfaction, they might be expected to reduce the demand for trade unions. This possibility forms the basis of what has become known as the HRM-substitution explanation of union decline. The argument is that unions may become redundant in the eyes of workers (and employers) because of "the effects that positive employer practices ... have in reducing the causes of unionism, i.e., worker dissatisfaction" (Fiorito 2001:335; italics in original).

This paper explores empirically whether $\mathrm{HRM} /$ union substitution has been a major factor in the decline of trade unionism in Britain. It asks whether there is indeed a link between the rise of HRM and declining trade unionism in British workplaces. To investigate this question, we use rich data on workplaces over time from the British Workplace Industrial/Employee Relations Surveys for 1980, 1984, 1990, and 1998.

\section{HRM Substitution in Britain}

The initial tendency to associate HRM practices with non-unionism was perhaps never as strong in the United Kingdom as it was in the United States, except when the practices were associated with U.S. multinationals. A lot of the discussion of HRM as an alternative to trade unions never appeared in published sources, but remained as a point of debate and speculation in conferences and seminars. HRM was often assumed to be antithetical to trade unionism, and hence much of the subtext of the debate concerned the future of industrial relations as a field (Godard and Delaney 2000). Keith Sisson, editor of a textbook on personnel management, summed up the published sources well in his introduction to the book's second edition: "Although there are formulations which give an important place to trade unions ..., most are silent on the issues or assume a nonunion environment" (Sisson 1994:12). From this, he wrote, we can infer that these writers regard unions as "at best unnecessary and at worst to be avoided."

At least one British commentator, however, did explicitly associate HRM with nonunionism: "An organisation pursuing HRM," he wrote, "will almost always prefer a non-union path, emphasising individual rather than collective arrangements" (Guest 1989:48) Yet while HRM might be associated with non-unionism, non-unionism "unfortunately" could not be equated with HRM, Guest noticeably added, as "a company may pursue non-union policies or remain fortuitously non-union without practising HRM."

The implication is that HRM is viewed as a major, if not the only effective, means of remaining non-union. Consistent with that, HRM is inherent to the definition of union substitution in some of the U.S. literature, certainly when distinctions are made between union substitution and union suppression. When Kochan (1980:183) first made the distinction-on the basis that direct union suppression involved "hard line opposition" through, for example, the use of blacklists, while union substitution was comparatively indirect-he certainly associated substitution with the growth of personnel management. More recently, Fiorito (2001:335) similarly made the distinction on the basis that "union suppression refers to direct attacks on symptoms of "unionism' (pro-union attitudes, intentions or actions) among workers" (italics in original). Since union substitution refers to employer practices designed to offer good pay and conditions or certain kinds of employee involvement, it is often conceived as being aimed at reducing worker dissatisfaction. Given that for Fiorito the adoption of such practices does not have to be con- 
sciously motivated by anti-unionism, any increase in their use that acts to enhance job satisfaction and discourage unionism could be taken to be union substitution.

Nonetheless, this prejudges too much ahead of empirical research on the purported link between HRM and non-unionism. Fiorito has in fact implicitly recognized the empirical nature of the question by designing and conducting studies to test whether HRM practices do indeed act as substitutes for unions (Fiorito 2001; Fiorito et al. 1987).

\section{Union Decline and the Increased Incidence of HRM Practices}

The sharp union decline in Britain that dates from 1979 is by now well known. Aggregate union density showed a remarkable stability in the postwar period (at around 40-45\% membership), followed by a sharp rise in the 1970 s, but then an even sharper fall from the late 1970s onward. Since 1979 aggregate union density has trended downward so that, by the end of the 1990 s, less than $30 \%$ of workers were members of trade unions. ${ }^{1}$

Alongside the evidence on the decline of unionization in the United Kingdom is research demonstrating that managers' increasing interest in HRM has translated into increased adoption of HRM practices. Wood and Albanese (1995:232-34) showed that the use of an extensive set of 15 HRM practices typically associated with high-involvement, high-commitment, or high-performance management-including team briefing, team working, formal assessment, merit pay, flexible job descriptions, and quality circles-all increased in their sample of 132 U.K. manufacturing plants between 1986 and 1990. Team briefing and flexible

\footnotetext{
${ }^{1}$ For selected years, aggregate union density was as follows: $1946-43 \% ; 1950-41 \% ; 1960-41 \% ; 1970-$ $46 \% ; 1975-51 \% ; 1980-52 \% ; 1985-46 \% ; 1990-$ $38 \% ; 1995-32 \% ; 2003-29 \%$. Sources for these numbers are Price and Bain (1983), Waddington (1992), Cully and Woodland (1998), and Hicks and Palmer (2004).
}

job descriptions had the highest rate of increase.

For a similar period in the subsequent decade, a study of manufacturing showed increases in both the adoption and extent of use by companies of three key highinvolvement practices-team working, empowerment, and learning culture (Wood et al. 2005). Analyses of the British Workplace Employee Relations Survey of 1998 have also documented the rise of direct communication methods and certain kinds of pay systems (Forth and Millward 2002; Millward et al. 2000; Sisson 1993). Several more qualitative studies (for example, for the United Kingdom, Clark 1995; Scott 1994; Starkey and McKinlay 1993:40-81; and Wickens 1987) have concentrated on the development of HRM practices in the past two decades, Storey's (1992) being the first to document the freshness of these in key U.K. organizations (as Kochan et al. [1986] and Appelbaum and Batt [1994] did for the United States).

\section{Existing Empirical Work from Britain}

To date, empirical research on the link between HRM practices and unionism has almost exclusively been based on point-intime cross-sectional analysis. Wood (1996), examining the full range of HRM practices in U.K. manufacturing, found that unionized workplaces did not differ from nonunionized workplaces in the extent of either major HRM practices or, more generally, "high commitment management" (as judged by a composite measure) in either 1986 or 1990 . Appraisal and merit pay were, however, more likely to be used in non-unionized plants, and the rate of change in high-commitment management between 1986 and 1990 was greater in nonunion plants.

Various analyses of aspects of the Workplace Industrial/Employee Relations Survey Series (of 1980, 1984, 1990, and 1998) have explored the link between human resource management practices and unionism. Most of these studies have concentrated on merit pay and non-union voice mechanisms and have concluded that they 
are not associated with non-unionism, being either neutral with respect to union recognition or positively associated with it (Sisson 1993; Cully et al. 2000; Gospel and Willman 2003).

Wood and de Menezes (1998) developed a composite measure of high-commitment management based on a mixture of data from WIRS for 1990 and a sister survey from 1990-91 (the Employers' Manpower and Skills Practices Survey) and found that this variable had no association with unionism. Analysis of a fuller range of HRM practices that were included for the first time in the WIRS/WERS series in 1998 found that the number of these practices used was associated with unionism (Cully et al. 2000:11011 ), but that this was mostly because they were especially widespread in large private sector workplaces and throughout the public sector.

A more in-depth analysis of the practices that were included in Cully et al.'s aggregate index of high commitment by Wood, de Menezes, and Lasaosa (2003) revealed that the relationship was more complex. The family-friendly practices, for example, and internal labor market employment practices included in Cully et al.'s index were not among the core high-involvement practices associated with changes in work organization. The validity of indices based on simply aggregating practices is questionable. Using their superior measures, Wood et al. (2003) found no strong relationship between union recognition or density and high-involvement management (nor, indeed, family-friendly management).

Forth and Millward (2002) conducted a more direct assessment of the union substitution hypothesis, but again only using crosssectional data (the 1998 Workplace Employee Relations Survey). They tested to see if direct communication channels were more prevalent where managers reported that they were generally not in favor of union membership than where managers were either neutral or positive toward unions. Forth and Millward first examined the subsample of workplaces with union recognition and then the non-union subsample, and found that direct commu- nication was unrelated to management's orientation toward unionism in the unionized sample. In the non-unionized sample the existence of some direct communication channels was related to negative attitudes toward unions on the part of management, but the extent of their use was greater where these attitudes were positive. The authors concluded that managers in nonunion workplaces attempting union substitution provide the minimum direct communication necessary and "do not provide further channels of communication that might be superfluous to the aim of union avoidance" (p. 23). This conclusion seems inconsistent with the union substitution thesis, and chimes more with Millward et al.'s (1992:350-65) earlier argument that the previously union-based British system of industrial relations has not been replaced by an alternative union-free model of employee representation.

\section{Interpretation}

Regardless of whether the relationship between HRM and unionism can be gleaned from cross-sectional analysis, any association that does exist could reflect a variety of processes. First, those who associate HRM with non-unionism may see the relationship simply as a transitional state or aberration. For example, Guest by 1995 admitted the co-existence of unionism and HRM, but implied that this could reflect that one or other was in a weak form: either the trade unionism was not robust or the HRM was fragmented or limited (Guest 1995:121). Moreover, statistical results could, to some extent, be mirroring the rise of industrial relations situations in which neither HRM nor unionism existed; this is what Guest (1995:125-27) called the black hole cases, or Sissons (1993:207) referred to as the bleak houses. According to Guest, HRM could not exist at high levels of unionization. Consistent with this view, he certainly saw a mutually supportive relationship between unions and HRM as less likely than "black holes" or "bleak houses"-much as Millward et al. (1992) had, a few years before. Any meaningful juxtaposition of 
unions and HRM along the mutual gains lines is by implication dependent on a change of union attitudes so that they embrace the HRM model. This implies that union members accept a role in enhancing economic performance, which in turn means that they accept the validity of the purported HRM-performance link. The implication is that the mutual gains for employees arise regardless of the presence of a union. Subsequently, Guest and Conway (1999) reported research that bore this out, as they observed that a high rate of adoption of HRM was associated with higher job satisfaction and commitment and reduced intentions to leave regardless of the union status of the individual. Further, those employees in unionized workplaces with little or no HRM had more negative attitudes than their equivalents in the non-union sector (that is, those in Guest's black hole).

Second, and linked to this, there is the possibility that the cross-sectional analysis masks multiple processes. There may be cases in which HRM and unionism are mutually supportive, as they seemingly were in the original Saturn experiment in the United States (Rubinstein and Kochan 2001); cases in which managers are using HRM to undermine an existing union or at least reduce its influence; and cases in which it is being used to keep unions at bay, alongside the black hole cases. There may also be a separation of the major HRM practices from unionism, with the former focused on changing task systems, the latter on governance. This is consistent with the more general point that the relationship between HRM practices and unionism may vary across practices, as Fiorito et al. (1987) indeed observed in their study of the effects of human resource practices on voting behavior in union organizing campaigns (see also Fiorito 2001).

In the most prominent HRM literature, that which has sought to test HRM's performance effects, quite diverse practices are taken to fall under the umbrella of HRM. They can be classified as practices concerned with job and work design (particularly with local empowerment), communications and representation, skill acquisi- tion and training, appraisal, recruitment and selection, compensation, and internal mobility (Appelbaum et al. 2000; Wood and Wall 2002). Several of the practices that fall under these headings are ones that unions have campaigned for or that are at least consistent with their demands, the most obvious being representation, training, job security, fair selection processes, and priority given to internal recruitment. Yet this is not to deny that if management were to offer these practices independently of employee pressure, dissatisfactions that spur unionism might disappear, reducing workers' willingness to join unions. Nonetheless, some practices-especially functional flexibility in a situation of negotiated work rules and job demarcations-may constitute substitutes for union-inspired rules and practices. As such, these may bring their own problems for workers, such as an increase in workloads, in supervisors' power, and in the scope for arbitrary management, as well as erosion of the union's power base.

The practices that most directly constitute alternatives to unions are those that can replace bargaining and voice roles. More specifically, there are two core substitutes for unions: forms of individualized pay determination such as individual bargaining or imposed merit- and performance-related pay awards, and methods of communication that purport to give workers a direct voice and avoid any third party such as a union or at least union representatives. Neither of these is likely to offer full alternatives to unions. First, under individualized pay determination, individuals negotiate without the strength of their fellow workers, and awards may be subject to the arbitrariness of managers, one of the very forces that unions were historically established to counter. Second, direct or non-union representative communication methods may offer lower levels of involvement and information-sharing, providing consultation rather than bargaining, and may not have the formal independence from management that the union has. Nonetheless, such practices remain the ones that are most important for testing the link between HRM and unionization. 
Given the above considerations, the key test of union substitution is whether the increased adoption of HRM practices over time led to declines in unionism that are detectable after the analysis controls for the influence of other factors, thus allowing us to conclude that HRM systems acted to replace collective bargaining and union voice. Therefore the issue of substitutability is best explored with data on direct substitutes for unions over time. This is consistent with Fiorito's (2001:351) conclusion, based on his finding of only modest support for union substitution in a study of the effects of human resource practices on union voting intentions, that we require measures of "the use of HR practices over time" to really assess "the extent to which they have contributed to the decline of unions over recent decades." It is this crosstime approach emphasizing dynamics that we adopt in our empirical investigation.

\section{The Study}

\section{Data Description}

The data used in this paper are drawn from the British Workplace Industrial/ Employee Relations Surveys of 1980, 1984, 1990, and 1998. These are workplace-level surveys ${ }^{2}$ containing rich data on the industrial relations environment of workplaces that have been widely used by researchers to study a range of issues (see the bibliography of Millward et al. 2002, for details of these studies). Of most relevance for our analysis is the fact that the surveys were carried out over time, as this permits us to address the question of whether HRM adoption paralleled union decline. The survey data contain a number of measures of union presence and of HRM practices. The crosstime angle offered by the four cross-sec-

\footnotetext{
${ }^{2}$ The first three surveys were representative samples of establishments with at least 25 employees, while the 1998 survey lowered this size threshold to 10 employees. To maintain consistency over time, we restrict our analysis to workplaces with at least 25 employees.
}

tions is important, as we wish to see whether the rapid union decline over the period corresponded in some way with changes in the incidence of HRM practices.

\section{Measures of Union Presence and HRM}

The union data in the WIRS/WERS series have been used by many researchers, both to look at union decline (Disney, Gosling, and Machin 1994, 1995; Machin 2000, 2003) and to study the economic effects of trade unions (Millward et al. 2002). The usual measure on which researchers focus is trade union recognition-whether management recognizes trade unions for collective bargaining purposes-but there are also data on workplace-level union density (the proportion of workers who are union members) and union coverage (the proportion of workers covered by collective bargaining).

The coverage of data on HRM variables became broader over the series, so that the 1998 survey covered most areas associated with HRM. Fortunately for our present concerns, the variables that have been included throughout the series (or in at least three surveys) relate to pay methods or employee voice, which are most apposite for testing the HRM/substitution hypothesis. For our empirical analysis we have therefore identified the following variables that we can observe over time (with those years that are available on a consistently defined basis in square brackets):

- the incidence of flexible pay (profit-sharing or share ownership) [1984, 1990, 1998, trading sector workplaces only];

- the presence of a Joint Consultative Committee $[1980,1984,1990,1998]$;

- the presence of problem-solving groups [1990, 1998];

- whether team briefings occur [1984, 1990, 1998];

- whether there are regular meetings in which management communicates or consults with the entire work force present [1984, 1990, 1998];

- whether management makes systematic use of a management chain for communication 
[1984, 1990, 1998];

- whether a suggestions scheme is in operation [1984, 1990, 1998]; and

- whether the workplace has a personnel specialist in place [1980, 1984, 1990, 1998].

\section{Analysis Strategy}

We start by examining whether, in the era of union decline, HRM practices more rapidly permeated non-union workplaces than unionized workplaces. If they did, this would suggest that HRM practices do increasingly provide a voice for workers in non-union environments, and may well make trade unions anachronisms in the workplace. In other words, the implication would be that in this world of HRM, workers do not need union representation in their workplace to ensure that grievance procedures, health and safety arrangements, and other forms of involvement are there for them if required. The first approach we adopt thus considers differences over time in the use of HRM practices in the union and non-union sectors. This enables us to look at whether one can identify differential trends through time in HRM incidence between union and non-union workplaces. If HRM substitution is present, we ought to see faster increases in HRM in the non-union sector.

An observed correlation between nonunionism and HRM could, however, merely reflect a higher presence of HRM practices in newer workplaces, where unionization is especially low. That is, because HRM practices are themselves relatively new, it is plausible that they could be taken up more by new workplaces than by established ones; and it is well established that unions have organized much less consistently in newer British workplaces than in older ones (Machin 2000, 2003). To ensure that we are not conflating workplace age and union status effects, our second approach therefore considers whether the incidence of HRM is higher in newer workplaces than in older ones, and thus is a stronger test than the first approach.

Finally, we consider longitudinal data on workplaces and industries and explore whether the rise of HRM has, in fact, gone hand-in-hand with union decline. While the data are for only a limited number of HRM practices, we are able to look at the dynamics of change to see whether withinworkplace or within-industry changes in unionization display any correlation with changes in HRM incidence. We do this in two ways: first, by asking whether unionized workplaces that introduced HRM practices between 1990 and 1998 saw falls in union presence relative to those that did not introduce practices; and second, by modeling changes in HRM and unionism in industries between 1980 and 1998.

\section{Union/Non-Union Differences in HRM Incidence over Time}

\section{Descriptive Statistics}

Sharp union decline is revealed in the WIRS/WERS data since 1980. Panel A of Table 1 shows that the percentage of establishments recognizing trade unions for collective bargaining fell from $64 \%$ to $42 \%$ between 1980 and 1998 . Union density and coverage also fell sharply (to $36 \%$ and $41 \%$, respectively) over the same time period. ${ }^{3}$

Panel $B$ of Table 1 gives means of the HRM variables over the relevant cross-sections. For most HRM practices-particularly flexible pay, team briefing, and having a personnel specialist-the table shows increased incidence. But this is not true of all measures. The presence of the more traditional Joint Consultative Committee actually falls, and the frequencies of some of the other practices (regular meetings with senior management, presence of a management chain) remain fairly constant over time.

\section{Changes over Time by Union Status}

Table 2 shows changes over time in the incidence of HRM practices separately for union and non-union workplaces, and also

\footnotetext{
${ }^{3}$ Note that the 1980 number for density is based only on full-time workers (see Millward, Bryson, and Forth 2000).
} 
Table 1. Changes in Union Presence and the Incidence of HRM Practices over Time (Proportions).

\begin{tabular}{lcccc}
\hline & \multicolumn{4}{c}{ Year } \\
\cline { 2 - 5 } Variable & 1980 & 1984 & 1990 & 1998 \\
\hline & A. Union Variables & & & \\
Union Recognition & .64 & .66 & .53 & .42 \\
Union Density & .62 & .58 & .48 & .36 \\
Union Coverage & - & .71 & .54 & .41 \\
& B. HRM Variables & & & \\
Flexible Pay & - & .30 & .54 & .50 \\
Joint Consultative Committee & .34 & .34 & .29 & .29 \\
Problem Solving Groups & - & - & .35 & .42 \\
Team Briefing & - & .36 & .48 & .53 \\
Regular Meetings with Senior Management & -.34 & .41 & .37 \\
Management Chain & - & .62 & .60 & .60 \\
Suggestion Schemes & .25 & .28 & .33 \\
Personnel Specialist & .27 & .27 & .27 \\
\hline
\end{tabular}

Notes:

Aggregate weighted proportions (that is, proportions across all establishments with 25 or more workers) in Panel A are taken from the sourcebooks for the 1980, 1984, and 1990 Workplace Industrial Relations Surveys and the 1998 Workplace Employee Relations Surveys (1980: Daniel and Millward 1983; 1984: Millward and Stevens 1986; 1990: Millward et al. 1992; 1998: Cully at al. 1998, 1999). For 1998 recognition data, recognition is recoded to zero for fifteen workplaces that recognized teacher unions but that in fact had pay set by the Pay Review Bodies (this follows the same procedure as in Chapter 10 of Cully at al. 1999). John Forth and Neil Millward kindly provided the serial codes for these fifteen workplaces.

Panel B weighted proportions are the authors' own calculations from the WIRS/WERS data.

${ }^{a}$ Union density is for full-timers in 1980 and all workers in other years.

displays comparisons between the two sectors. The table shows the percentage of workplaces with each of the practices for a start year and end year, and the change in the percentage between those years. The penultimate column shows the gap between sectors in those changes in percentages. For example, between 1984 and 1998, the percentage of workplaces that had flexible pay increased by 17 percentage points in the union sector and by 25 percentage points in the non-union sector, making for a gap of 8 percentage points between the changes in the two sectors. The final column displays the level of statistical significance of those inter-sectoral differences.

The numbers in Table 2 reveal several patterns. First, at a given point in time, the incidence of the HRM factors tends to be higher in the union sector than in the nonunion sector. At face value, this would suggest a complementarity between unions and HRM practice. However, of most interest to us is whether there were any changes in HRM practices over the period of union decline. Table 2 shows an increased adoption of most practices in both sectors, but the results concerning increased substitution into the non-union sector are uneven (see the last two columns). Indeed, the only practice that seems to show a strong, statistically significant, faster differential increase in incidence in non-union workplaces than in union workplaces is flexible pay. As noted above, there was an eight percentage point faster increase in flexible pay incidence in the non-union sector-a statistically significant difference between sectors, as shown by the p-value of the significance test given in the final column. However, this really is the only evidence of substitution. The next nearest is a four percentage point increase in Joint Consultative Committees, with an associated p- 
Table 2. Union/Non-Union Differences in

Changes in the Incidence of HRM Practices over Time.

\begin{tabular}{|c|c|c|c|c|c|c|c|c|c|}
\hline \multirow[b]{2}{*}{ HRM Practice } & \multirow[b]{2}{*}{$\begin{array}{l}\text { Start and } \\
\text { End Years }\end{array}$} & \multicolumn{3}{|c|}{ Union Sector } & \multicolumn{3}{|c|}{ Non-Union Sector } & \multirow{2}{*}{$\begin{array}{l}\text { Difference } \\
\text { in Change } \\
\text { between } \\
\text { Non- } \\
\text { Union/ } \\
\text { Union } \\
\text { Sectors }\end{array}$} & \multirow{2}{*}{$\begin{array}{c}\text { Test } \\
\text { of } \\
\text { Signif. of } \\
\text { Difference } \\
\text { in Change } \\
\text { (p-value) }\end{array}$} \\
\hline & & $\begin{array}{c}\text { Percent } \\
\text { in Start } \\
\text { Year }\end{array}$ & $\begin{array}{c}\text { Percent } \\
\text { in End } \\
\text { Year }\end{array}$ & Change & $\begin{array}{c}\text { Percent } \\
\text { in Start } \\
\text { Year }\end{array}$ & $\begin{array}{l}\text { Percent } \\
\text { in End } \\
\text { Year }\end{array}$ & Change & & \\
\hline $\begin{array}{l}\text { Flexible Pay } \\
\text { Joint Consultative }\end{array}$ & 1984,1998 & 38 & 55 & 17 & 23 & 48 & 25 & 8 & .04 \\
\hline $\begin{array}{l}\text { Committee } \\
\text { Problem Solving }\end{array}$ & 1980,1998 & 41 & 38 & -3 & 21 & 22 & 1 & 4 & .11 \\
\hline Groups & 1990,1998 & 39 & 49 & 10 & 30 & 37 & 7 & -3 & .26 \\
\hline $\begin{array}{l}\text { Team Briefing } \\
\text { Regular Meetings } \\
\text { with Senior }\end{array}$ & 1984,1998 & 39 & 58 & 19 & 31 & 49 & 18 & -1 & .69 \\
\hline Management & 1984,1998 & 36 & 41 & 5 & 30 & 35 & 5 & 0 & .83 \\
\hline Management Chain & 1984,1998 & 68 & 70 & 2 & 51 & 52 & 1 & -1 & .75 \\
\hline Suggestion Schemes & 1984,1998 & 31 & 42 & 11 & 15 & 26 & 11 & 0 & .82 \\
\hline Personnel Specialist & 1980,1998 & 23 & 32 & 9 & 12 & 23 & 11 & 2 & .51 \\
\hline
\end{tabular}

value of .11. For the other HRM practices, we find very similar patterns of change between the non-union and union sectors, all statistically insignificant (in the +2 to $-3 \%$ range of differences).

To the practice-specific results shown in Table 2, it is worth adding a brief mention of the pattern of results obtained when we look at the practices jointly. Notably, there is no statistically significant differential increase in the use of multiple practices across sectors. In 1984, union sector workplaces had, on average, 2.67 of the seven HRM practices for which we have data over the 1984-98 period, and this figure rose to 3.30 by 1998 ; in the non-union sector the number rose from 1.85 to 2.53 over the same period. The scale of change is similar across the two sectors (a rise of .53 in the union sector and .68 in the nonunion sector), and in statistical terms one cannot reject the null hypothesis of the same change across sectors ( $p$-value of significance test $=.68)$.

\section{HRM Substitution and Workplace Age}

\section{Links with Workplace Age}

The evidence so far has not revealed much in support of the HRM substitution thesis. In this section we consider the question another way, looking instead at the extent to which newer workplaces differentially introduced HRM practices. We adopt this approach in the light of the evidence that union decline in Britain has been driven, at least partially, by unions' failure to secure recognition and build up membership in newer workplaces (Machin 2003). Consider the upper panel of Table 3 . Among workplaces set up before 1980,63\% recognized unions for collective bargaining, and union membership density was $58 \%$. In stark contrast, union recognition and density were $36 \%$ and $31 \%$, respectively, in workplaces set up in the 1980 s, and only $27 \%$ and $22 \%$, respectively, in those set up in the 1990s. Hence one sees very sharp falls in unionization rates by age of workplace. Columns (6) and (7) of Table 3 show the scale of the declines, which was very strong in statistical terms (the numbers in parentheses are standard errors).

This pattern offers promise as a means to try and identify HRM substitution. In new workplaces the absence of unions may well mean that managers used HRM to pre- 
Table 3. Changes in Union Status and in the Incidence of HRM Practices over Time Related to Age of Workplace.

\begin{tabular}{|c|c|c|c|c|c|c|c|}
\hline Years of Data & Measure & $\begin{array}{c}\text { (3) } \\
\text { Set up } \\
\text { before } \\
1980\end{array}$ & $\begin{array}{l}\text { (4) } \\
\text { Set } u p \\
\text { in } \\
1980 s\end{array}$ & $\begin{array}{c}\text { (5) } \\
\text { Set up } \\
\text { in } \\
\text { 1990s }\end{array}$ & $\begin{array}{c}(6) \\
\text { Gap 1980s } \\
- \text { before } 1980 \\
(4)-(3)\end{array}$ & $\begin{array}{c}\text { (7) } \\
\text { Gap 1990s } \\
- \text { before } 1980 \\
(5)-(3)\end{array}$ & $\begin{array}{c}(8) \\
\text { Number } \\
\text { of } \\
\text { Workplaces }\end{array}$ \\
\hline \multicolumn{8}{|c|}{ A. Differences in Union Status by Age of Workplace } \\
\hline $1980,1984,1990,1998$ & Union Recognition & .63 & .36 & .27 & $-.27(.02)$ & $-.36(.02)$ & 8,022 \\
\hline $1980,1984,1990,1998$ & Union Density & .58 & .31 & .22 & $-.27(.01)$ & $-.36(.02)$ & 7,028 \\
\hline \multicolumn{8}{|c|}{ B. Differences in HRM Incidence by Age of Workplace } \\
\hline $\begin{array}{l}1980,1984,1990,1998 \\
1984,1990,1998\end{array}$ & $\mathrm{JCC}$ & .33 & .24 & .26 & $-.09(.01)$ & $-.07(.02)$ & 8,004 \\
\hline Trading Sector & Flexible Pay & .42 & .50 & .52 & $.08(.02)$ & $.10(.02)$ & 4,194 \\
\hline 1990,1998 & Problem-Solving Groups & .39 & .38 & .37 & $-.01(.02)$ & $-.02(.02)$ & 3,955 \\
\hline $1984,1990,1998$ & Team Briefing & .45 & .46 & .50 & $.01(.02)$ & $.05(.02)$ & 5,961 \\
\hline \multirow[t]{2}{*}{$1984,1990,1998$} & Regular Meetings with & & & & & & \\
\hline & Senior Management & .36 & .40 & .42 & $.05(.02)$ & $.07(.02)$ & 5,978 \\
\hline $1984,1990,1998$ & Management Chain & .61 & .63 & .53 & $.02(.02)$ & $-.07(.02)$ & 5,978 \\
\hline $1984,1990,1998$ & Suggestion Schemes & .28 & .29 & .32 & $.01(.01)$ & $.04(.02)$ & 5,977 \\
\hline $1980,1984,1990,1998$ & Personnel Specialist & .32 & .42 & .48 & $.10(.02)$ & $.16(.02)$ & 4,194 \\
\hline
\end{tabular}

Notes: Standard errors in parentheses.

empt unionism, or that workers, either as a consequence or independently, preferred an alternative form of voice. If so, we should see more rapid inflows of HRM practices into newer workplaces than into older, more unionized workplaces. This is what we first look at in the lower panel (B) of Table 3, which presents indicators for HRM practices using the same structure as Panel A.

The numbers in Table 3 show something of a mixed pattern, but they are in part conducive to the idea that HRM practices were more likely to be present in newer workplaces. The strongest evidence in favor of this distribution is for flexible pay and for the presence of a personnel specialist. The prevalence of flexible pay was 8 percentage points higher in workplaces set up in the $1980 \mathrm{~s}$, and 10 percentage points higher in those set up in the 1990s, than in older workplaces; and corresponding numbers for the presence of a personnel specialist were 10 and 16 percentage points higher, respectively. Age of workplace gaps are less marked for some of the other measures, but most are positive, the main exception being the more traditional practice, the Joint Consultative Committee.
However, over the time period being studied there were also some important compositional changes, such as the increased incidence of smaller workplaces, and a move away from manufacturing to services. So we next present some empirical estimates of the relationship with age of workplace derived from statistical models that control for such shifts in composition. This is important because some of these HRM practices may be much more likely to be prevalent in certain workplaces. For example, larger workplaces are more likely to have a personnel specialist than are their smaller counterparts.

\section{Statistical Estimates}

Table 4 reports estimates derived from probit equations in which either union status measures (upper panel) or various measures of HRM incidence (lower panel) were the dependent variables. The table reports the marginal effects of workplace age derived from the estimated probit equations. In Table 4 (as in Table 3) workplace age is defined as either "set up in the 1980s" or "set up in the 1990s." A number of control variables were in- 
Table 4. Statistical Estimates of the Relationship between Changes in Union Status and the Incidence of HRM Practices over Time and Age of Workplace.

\begin{tabular}{|c|c|c|c|c|}
\hline Years of Data & Measure & $\begin{array}{l}\text { Set up } \\
\text { in 1980s }\end{array}$ & $\begin{array}{l}\text { Set up } \\
\text { in 1990s }\end{array}$ & Sample Size \\
\hline \multicolumn{5}{|c|}{ A. Union Equations } \\
\hline $1980,1984,1990,1998$ & Union Recognition & $\begin{array}{l}-.120 \\
(.019)\end{array}$ & $\begin{array}{l}-.100 \\
(.026)\end{array}$ & 7,483 \\
\hline $1980,1984,1990,1998$ & Union Density & $\begin{array}{l}-.102 \\
(.011)\end{array}$ & $\begin{array}{l}-.106 \\
(.016)\end{array}$ & 6,623 \\
\hline \multicolumn{5}{|c|}{ B. HRM Equations } \\
\hline $1984,1990,1998$ Trade Sector & Flexible Pay & $\begin{array}{l}.003 \\
(.024)\end{array}$ & $\begin{array}{l}-.024 \\
(.033)\end{array}$ & 3,915 \\
\hline $1980,1984,1990,1998$ & JCC & $\begin{array}{l}-.052 \\
(.021)\end{array}$ & $\begin{array}{l}-.019 \\
(.028)\end{array}$ & 7,466 \\
\hline 1990,1998 & Problem-Solving Groups & $\begin{array}{l}.000 \\
(.021)\end{array}$ & $\begin{array}{l}-.010 \\
(.027)\end{array}$ & 3,640 \\
\hline $1984,1990,1998$ & Team Briefing & $\begin{array}{l}-.003 \\
(.020)\end{array}$ & $\begin{array}{c}.011 \\
(.027)\end{array}$ & 5,480 \\
\hline $1984,1990,1998$ & $\begin{array}{l}\text { Regular Meetings with Senior } \\
\text { Management }\end{array}$ & $\begin{array}{l}-.003 \\
(.019)\end{array}$ & $\begin{array}{c}.046 \\
(.027)\end{array}$ & 5,497 \\
\hline $1984,1990,1998$ & Management Chain & $\begin{array}{l}.001 \\
(.018)\end{array}$ & $\begin{array}{l}-.013 \\
(.025)\end{array}$ & 5,497 \\
\hline $1984,1990,1998$ & Suggestion Schemes & $\begin{array}{l}-.020 \\
(.019)\end{array}$ & $\begin{array}{l}-.008 \\
(.027)\end{array}$ & 5,496 \\
\hline $1980,1984,1990,1998$ & Personnel Specialist & $\begin{array}{l}-.010 \\
(.022)\end{array}$ & $\begin{array}{c}.004 \\
(.030)\end{array}$ & 7,483 \\
\hline
\end{tabular}

Notes: Probit marginal effects; standard errors in parentheses. All specifications include controls for establishment size (dummies for 50-99, 100-199, 200-499, 500-999, 1000+ workers relative to 25-49), female proportion, part-time proportion, part of a larger organization, private sector, industry (one-digit industry dummies), and survey year.

cluded in the probit equations, which were chosen to capture the most important compositional changes in the economy over the time period under study. The variables included are establishment size (five dummy variables compared to a base of 25-49 workers), whether the establishment was part of a larger organization, the proportions of part-time and female workers, whether the workplace was in the private sector, and a set of one-digit industry dummies.

The upper panel of Table 4 reconfirms what is known from earlier work, revealing union recognition to be around 10 to 12 percentage points lower in workplaces set up in the 1980 s or 1990 s conditional on the factors measuring compositional change.
This is a sizeable effect, and the same is true for union density, as given in the second specification of the upper panel, where 1980 s and 1990s effects are very similar indeed.

The lower panel (B) of Table 4 considers the HRM practices. It is immediately striking that the inclusion of the controls is much more important for the HRM regressions than for the union ones. In statistical terms, all of the correlations with workplace age are wiped out in the statistical models. Unlike for union decline, the changing composition of workplaces seems to fully explain the link between the incidence of HRM practices and workplace age. This, like the evidence reported in the previous section, seems inconsistent with 
Table 5. Differences in Age of Workplace Effects by Union Status from Models of the Incidence of HRM Practices.

\begin{tabular}{|c|c|c|c|c|c|c|c|c|}
\hline \multirow[b]{2}{*}{ Years of Data } & \multirow[b]{2}{*}{$\begin{array}{l}(2) \\
\text { Set up } \\
\text { in } \\
\text { Measure }\end{array}$} & \multicolumn{2}{|c|}{ Union Workplace } & \multicolumn{2}{|c|}{ Non-Union Workplace } & \multicolumn{2}{|c|}{$\begin{array}{c}\text { Non-Union/ } \\
\text { Union Difference }\end{array}$} & \multirow[b]{2}{*}{$\begin{array}{c}\text { Sample } \\
\text { Size }\end{array}$} \\
\hline & & $\begin{array}{l}(3) \\
\text { Set up } \\
\text { in } \\
1980 s\end{array}$ & $\begin{array}{l}\text { (4) } \\
\text { Set up } \\
\text { in } \\
1990 s\end{array}$ & $\begin{array}{l}\text { (5) } \\
\text { Set up } \\
\quad \text { in } \\
1980 s\end{array}$ & $\begin{array}{l}\text { (6) } \\
\text { Set up } \\
\text { in } \\
1990 s\end{array}$ & $\begin{array}{c}(7) \\
\text { Set up } \\
\text { in } 1980 s \\
(5)-(3)\end{array}$ & $\begin{array}{c}(8) \\
\text { Set up } \\
\text { in } 1990 s \\
(6)-(4)\end{array}$ & \\
\hline $\begin{array}{c}1984,1990,1998 \\
\text { Trading Sector }\end{array}$ & Flexible Pay & $\begin{array}{l}-.009 \\
(.037)\end{array}$ & $\begin{array}{l}.057 \\
(.052)\end{array}$ & $\begin{array}{l}.020 \\
(.031)\end{array}$ & $\begin{array}{l}-.053 \\
(.040)\end{array}$ & $\begin{array}{l}.029 \\
(.047)\end{array}$ & $\begin{array}{l}-.110 \\
(.061)\end{array}$ & 3,915 \\
\hline $1980,1984,1990,1998$ & JCC & $\begin{array}{l}-.018 \\
(.027)\end{array}$ & $\begin{array}{l}-.000 \\
(.037)\end{array}$ & $\begin{array}{l}-.074 \\
(.030)\end{array}$ & $\begin{array}{l}-.025 \\
(.039)\end{array}$ & $\begin{array}{l}-.056 \\
(.039)\end{array}$ & $\begin{array}{l}-.025 \\
(.050)\end{array}$ & 7,466 \\
\hline 1990,1998 & $\begin{array}{l}\text { Problem-Solving } \\
\text { Groups }\end{array}$ & $\begin{array}{c}.028 \\
(.029)\end{array}$ & $\begin{array}{l}.036 \\
(.037)\end{array}$ & $\begin{array}{l}-.022 \\
(.031)\end{array}$ & $\begin{array}{l}-.050 \\
(.037)\end{array}$ & $\begin{array}{l}-.049 \\
(.042)\end{array}$ & $\begin{array}{l}-.084 \\
(.048)\end{array}$ & 3,640 \\
\hline $1984,1990,1998$ & Team Briefing & $\begin{array}{l}-.008 \\
(.027)\end{array}$ & $\begin{array}{l}.041 \\
(.037)\end{array}$ & $\begin{array}{l}.022 \\
(.029)\end{array}$ & $\begin{array}{l}.004 \\
(.037)\end{array}$ & $\begin{array}{l}.030 \\
(.038)\end{array}$ & $\begin{array}{l}-.036 \\
(.049)\end{array}$ & 5,480 \\
\hline $1984,1990,1998$ & $\begin{array}{l}\text { Regular Meetings } \\
\text { with Senior } \\
\text { Management }\end{array}$ & $\begin{array}{l}-.017 \\
(.026)\end{array}$ & $\begin{array}{c}.011 \\
(.036)\end{array}$ & $\begin{array}{c}.022 \\
(.028)\end{array}$ & $\begin{array}{c}.089 \\
(.037)\end{array}$ & $\begin{array}{l}.039 \\
(.038)\end{array}$ & $\begin{array}{l}.077 \\
(.048)\end{array}$ & 5,497 \\
\hline $1984,1990,1998$ & $\begin{array}{l}\text { Management } \\
\text { Chain }\end{array}$ & $\begin{array}{l}-.015 \\
(.025)\end{array}$ & $\begin{array}{l}.032 \\
(.033)\end{array}$ & $\begin{array}{l}.034 \\
(.023)\end{array}$ & $\begin{array}{l}-.029 \\
(.033)\end{array}$ & $\begin{array}{l}.048 \\
(.031)\end{array}$ & $\begin{array}{l}-.061 \\
(.048)\end{array}$ & 5,497 \\
\hline $1984,1990,1998$ & $\begin{array}{l}\text { Suggestion } \\
\text { Schemes }\end{array}$ & $\begin{array}{l}-.019 \\
(.025)\end{array}$ & $\begin{array}{l}-.014 \\
(.034)\end{array}$ & $\begin{array}{l}.019 \\
(.030)\end{array}$ & $\begin{array}{l}.032 \\
(.037)\end{array}$ & $\begin{array}{l}.039 \\
(.039)\end{array}$ & $\begin{array}{l}.046 \\
(.049)\end{array}$ & 5,496 \\
\hline $1980,1984,1990,1998$ & $\begin{array}{l}\text { Personnel } \\
\text { Specialist }\end{array}$ & $\begin{array}{l}.010 \\
(.029)\end{array}$ & $\begin{array}{l}.040 \\
(.039)\end{array}$ & $\begin{array}{l}-.013 \\
(.031)\end{array}$ & $\begin{array}{l}-.018 \\
(.040)\end{array}$ & $\begin{array}{l}-.022 \\
(.041)\end{array}$ & $\begin{array}{l}-.057 \\
(.051)\end{array}$ & 7,483 \\
\hline
\end{tabular}

Notes: Probit marginal effects; standard errors in parentheses. All specifications include controls for establishment size (dummies for 50-99, 100-199, 200-499, 500-999, 1000+ workers relative to 25-49), female proportion, part-time proportion, part of a larger organization, private sector, industry (one-digit industry dummies), and survey year.

HRM substitution taking place during the period of union decline in Britain.

\section{Non-Union/Union Differences}

Before accepting that conclusion, however, we need to examine whether or not predominantly new non-union workplaces were increasingly introducing HRM practices. We do so in Table 5 , which reports the marginal effects of workplace age on the incidence of various HRM incidence measures derived from probit equations estimated separately for union and nonunion workplaces. HRM substitution related to workplace age predicts that one should see more of a positive new workplace effect in non-union workplaces. The table therefore presents coefficient estimates associated with indicators of whether workplaces were set up in the 1980s and 1990s for the union sector (columns 3 and 4 ), analogous effects for the non-union sector (in columns 5 and 6 ), and then nonunion/union gaps (columns 7 and 8).

Table 5 shows that the positive nonunion/union gaps that HRM substitution would predict are rarely seen. In fact, none of the non-union/union differences in columns (7) and (8) are positive and statistically significant, and many are actually negative. This result reflects the fact that a number of the non-union effects are negative and they rarely are more positive than the union effects. None of this supports the HRM/union substitution thesis.

\section{Longitudinal Changes in the Union-HRM Relation}

Our analysis so far rejects the idea that HRM substitution, in its orthodox sense of substituting between union and non-union sectors, has occurred. But one more possibility remains: that where the use of HRM has risen within the union sector, it weak- 
Table 6. Changes in Union Density (\%) Associated with Changes

in the Presence of HRM Practices in Unionized Workplaces, 1990-97.

\begin{tabular}{lccc}
\hline & Introduced Practice & Removed Practice & No Change \\
\hline Flexible Pay & -8.9 & -9.6 & -5.8 \\
Number of Workplaces & 87 & 42 & 319 \\
JCC & -8.6 & -8.8 & -5.8 \\
Number of Workplaces & 80 & 64 & 307 \\
\hline
\end{tabular}

Notes: Authors' own calculations from 1990-97 WIRS panel. The sample covers workplaces that recognized trade unions for collective bargaining purposes in 1990 and 1997.

ened unions. This would represent a form of HRM substitution occurring within the union sector.

We investigate this hypothesis by drawing on the longitudinal sample of workplaces that the WIRS/WERS series covered between 1990 and 1997. Due to limitations of the available data on HRM practices, however, we can only look here at the JCC and Flexible Pay measures. Table 6 shows the within-establishment change in union density broken down by the change, or lack thereof, in the status of each HRM practice (practice newly introduced; practice removed; or no change). The hypothesis that HRM substitution weakened unions within the union sector implies larger falls in union density in workplaces that introduced an HRM practice than in those that did not.

The results in Table 6 are not in line with that prediction. For example, although workplaces that introduced a JCC between 1990 and 1997 saw union density fall by 9 percentage points, density also fell by 9 percentage points in workplaces that removed a JCC and by 6 percentage points in workplaces where JCC status remained unaltered. The same pattern is true of Flexible Pay. While density fell by 9 percentage points in workplaces that introduced Flexible Pay, it also fell by 10 percentage points in those that abandoned the practice and by 6 percentage points in workplaces with no change in their use of flexible pay.

The results remain robust in regressions with the change in union density as the dependent variable and control variables including the 1990 to 1997 change in employment, the proportion of manual work- ers, and a set of one-digit industry dummies, as shown in Table 7. Overall, there seems to be little evidence of faster union decline in workplaces that introduced HRM practices in the 1990 s.

Another way of using the WIRS/WERS data to study longitudinal changes is to aggregate the workplace data in the four surveys of $1980,1984,1990$, and 1998 to industry level so as to study industry-level changes in the relationship between unionization and HRM incidence over time. To perform that exercise, we aggregated the data to 44 industries that we track over time. Table 8 reports the coefficients on various HRM practices from a regression in which the proportion of workplaces in the industry with recognized unions was the dependent variable and industry fixed effects were included in some of the equations. Where industry fixed effects were controlled for, one can infer the relationship between within-industry changes in unionization and within-industry changes in HRM practices. We can use the fixed effect equations to assess the following question about HRM substitution: in industries where HRM incidence went up by more, did unionization fall by more? Evidence confirming this would be a negative coefficient on the HRM measures in the industry fixed effects specifications reported in Table 8 .

Table 8 is structured to show results that enter the HRM incidence measures separately (in columns $1-7$, where no controls are included, and in columns 9-15, where controls are included) and all together (in column 8 , without controls, and in column 
Table 7. Changes in Union Density Associated with Changes

in the Presence of HRM Practices in Unionized Workplaces, 1990-97.

(Dependent Variable: Changes in Proportion Union Members, 1990-97)

\begin{tabular}{lccc}
\hline & Introduced Practice & Removed Practice & Sample Size \\
\hline Flexible Pay & $-.008(.025)$ & $-.017(.034)$ & 444 \\
JCC & $-.026(.027)$ & $-.042(.025)$ & 451 \\
\hline
\end{tabular}

Notes: All specifications include controls for change in log (employment), change in proportion manual, and a set of one-digit industry dummies; standard errors in parentheses.

16, with controls). The pattern of results shows that while there are a few negative coefficients, these are the exception to the rule, and only one of them is statistically significant (for Regular Meetings with Senior Management when no control variables are entered in column 4). In the specifications with control variables in the lower panel of Table 8 there is no evidence of union decline being faster where HRM incidence increased. As such, neither set of longitudinal data considered in this section supports the hypothesis of HRM substitution.

\section{Concluding Remarks}

In this paper we have considered one of the key hypotheses of modern industrial relations, namely that unionism has been replaced by alternative non-union forms of voice and communication through the adoption of HRM practices. Were such HRM substitution taking place, one would expect to see a swifter introduction of HRM practices in non-union workplaces than in unionized workplaces; certainly one would expect to find the presence of these practices and the absence of a recognized trade union, in the new kinds of workplaces being set up in recent years. A finding of a more rapid diffusion of HRM into nonunion workplaces would also cast doubt on the argument, expressed by those encouraging unions to embrace HRM, that HRM practices and unions can be complementary. Moreover, were such a pattern a longterm trend, it would seemingly contradict the "mutual gains" argument (Kochan and Osterman 1994) that HRM's performance effects will be enhanced when unions are present.

Our empirical investigation, using workplace data from the Workplace Industrial/ Employee Relations series of surveys in Britain between 1980 and 1998, uncovers no evidence to support the hypothesis of HRM/ union substitution, at least operating in the commonly accepted and frequently stated way, with HRM replacing unions. This finding emerges from several empirical strategies. First we compared changes over time in the incidence of HRM practices across union and non-union sectors, and found little difference between sectors. Second, we asked whether newer workplaces (because these have been shown to be more likely to be non-union) have experienced differentially faster HRM incidence. We were unable to find much evidence of such a pattern, and certainly we found no evidence of statistically significant union/nonunion differences. Third, an analysis of longitudinal changes also failed to yield any evidence of faster union decline in workplaces or industries with faster adoption of HRM practices. Overall, one can only conclude that HRM substitution does not seem to be a very important factor in explaining trade union decline in Britain. ${ }^{4}$

However, we do not know how generalizable these findings are to other countries. It is sometimes argued that in Britain managers have not fully embraced human re-

\footnotetext{
${ }^{4}$ See Pencavel (2004) for a general and wide-ranging account of other factors underpinning union decline in the United Kingdom.
} 
Table 8. Industry Panel (44 Industries) Relating Changes in Union Recognition to Changes in HRM Practices, 1980-98.

\begin{tabular}{|c|c|c|c|c|c|c|c|c|}
\hline & (1) & (2) & (3) & (4) & (5) & (6) & (7) & (8) \\
\hline Flexible Pay & $\begin{array}{l}.105 \\
(.070)\end{array}$ & & & & & & & $\begin{array}{c}.042 \\
(.069)\end{array}$ \\
\hline JCC & & $\begin{array}{c}.077 \\
(.092)\end{array}$ & & & & & & $\begin{array}{l}-.007 \\
(.095)\end{array}$ \\
\hline Team Briefing & & & $\begin{array}{l}.219 \\
(.081)\end{array}$ & & & & & $\begin{array}{c}.061 \\
(.090)\end{array}$ \\
\hline $\begin{array}{l}\text { Regular Meetings } \\
\text { with Senior } \\
\text { Management }\end{array}$ & & & & $\begin{array}{l}-.166 \\
(.088)\end{array}$ & & & & $\begin{array}{c}-.151 \\
(.078)\end{array}$ \\
\hline Management Chain & & & & & $\begin{array}{l}.160 \\
(.096)\end{array}$ & & & $\begin{array}{l}.048 \\
(.095)\end{array}$ \\
\hline Suggestion Schemes & & & & & & $\begin{array}{l}.166 \\
(.106)\end{array}$ & & $\begin{array}{l}.003 \\
(.094)\end{array}$ \\
\hline Personnel Specialist & & & & & & & $\begin{array}{c}.355 \\
(.061)\end{array}$ & $\begin{array}{c}.291 \\
(.081)\end{array}$ \\
\hline Controls & No & No & No & No & No & No & No & No \\
\hline R-Squared & .87 & .90 & .91 & .91 & .91 & .91 & .89 & .93 \\
\hline \multirow[t]{2}{*}{ Sample Size } & 176 & 130 & 132 & 132 & 132 & 132 & 176 & 130 \\
\hline & (9) & (10) & (11) & (12) & (13) & (14) & (15) & $(16)$ \\
\hline Flexible Pay & $\begin{array}{l}.097 \\
(.082)\end{array}$ & & & & & & & $\begin{array}{l}.103 \\
(.072)\end{array}$ \\
\hline JCC & & $\begin{array}{l}-.057 \\
(.091)\end{array}$ & & & & & & $\begin{array}{l}-.160 \\
(.122)\end{array}$ \\
\hline Team Briefing & & & $\begin{array}{l}.193 \\
(.089)\end{array}$ & & & & & $\begin{array}{l}.102 \\
(.085)\end{array}$ \\
\hline $\begin{array}{l}\text { Regular Meetings } \\
\text { with Senior } \\
\text { Management }\end{array}$ & & & & $\begin{array}{l}-.068 \\
(.092)\end{array}$ & & & & $\begin{array}{l}-.057 \\
(.085)\end{array}$ \\
\hline Management Chain & & & & & $\begin{array}{c}.057 \\
(.103)\end{array}$ & & & $\begin{array}{l}-.028 \\
(.112)\end{array}$ \\
\hline $\begin{array}{c}\text { Suggestion } \\
\text { Schemes }\end{array}$ & & & & & & $\begin{array}{l}.146 \\
(.099)\end{array}$ & & $\begin{array}{c}.022 \\
(.105)\end{array}$ \\
\hline $\begin{array}{l}\text { Personnel } \\
\text { Specialist }\end{array}$ & & & & & & & $\begin{array}{l}.264 \\
(.056)\end{array}$ & $\begin{array}{l}.261 \\
(.094)\end{array}$ \\
\hline Controls & Yes & Yes & Yes & Yes & Yes & Yes & Yes & Yes \\
\hline R-Squared & .91 & .92 & .93 & .93 & .93 & .93 & .91 & .94 \\
\hline Sample Size & 176 & 130 & 132 & 132 & 132 & 132 & 176 & 130 \\
\hline
\end{tabular}

Notes: Based on an estimation that aggregates the 1980, 1984, 1990, and 1998 WIRS/WERS establishment data to the industry level; weighted by industry cell sizes; standard errors in parentheses.

source management practices, adopting them in a largely piecemeal way. This may involve cherry-picking the latest fashion or introducing the practices that are most easily implemented. Fragmented adoption may also be common in the United States
(Appelbaum and Batt 1994:124), and it may be linked to the more general argument about the way in which Anglo-Saxon financial systems and corporate governance are said to encourage "short-termism." However, there is evidence to suggest a 
pattern to the use of human resource practices that is not consistent with the ad hoc adoption of such practices. Studies in the United Kingdom by Wood, in particular, using a variety of data sets, suggest some integrated use of practices (Wood and Albanese 1995; Wood and de Menezes 1998; de Menezes and Wood 2005; Wood et al. 2004), and Storey's (1992:113) report of the adoption of HRM practices in the 1980s described a growing systematic use of those practices during the period of his study. Moreover, similar work by Wood (1999) using Osterman's U.S. data set pointed to integrated use. Our analysis of changes in the aggregate use of HRM found no statistically significantly greater adoption of HRM practices in non-union workplaces than in unionized ones. If the results of our research are uniquely British in some way, there seems little cause to believe that the ad hoc adoption of practices accounts for that uniqueness.

It may also be that stronger substitution effects would be evident where management's attitudes toward unions are more markedly negative than in the United Kingdom. Some observers cite the United States as a decidedly union-unfriendly environment, and claim that HRM is being used more overtly there than in the United Kingdom as a form of union suppression. However, there have certainly been enough genuflections to the co-existence of unions and HRM practices in other countries (for example, Kochan et al. 1986; Weitbrecht 2003) to suggest that were this study replicated outside Britain, similar results might be found. Moreover, we have little evidence to indicate that strong anti-union employers, particularly in low-wage sectors of the economy, are any more likely to use any employee involvement, performancerelated pay, or sophisticated personnel methods than are their counterparts in the United Kingdom.

Its generalizability aside, this study has implications for the wider debate about industrial relations as a field of study, which has been largely fueled by events in AngloSaxon economies. If new management practices of the sort we have considered are actually no less likely (and possibly are more likely) to be introduced in the union sector than in the non-union sector, then an important premise undergirding some of the discussion of the future of industrial relations - that HRM and unionism are alternatives-comes under challenge. In fact, it may be the case that HRM is as complementary to the organization of work in unionized workplaces as it is elsewhere. Critical to this is a subject that we have not considered here: the nature of the collective use of HRM practices and the impact of their introduction on workplace performance, a question that is far from resolved in favor of the positive link (Wood 1999; Wood and Wall 2002) that is often assumed. A related question we have not investigated here is whether there are different reasons for introducing HRM practices in union and nonunion environments. Such matters remain firmly on the agenda for future research. 


\section{REFERENCES}

Appelbaum, Eileen, Thomas Bailey, Peter Berg, and Arne L. Kalleberg. 2000. Manufacturing Advantage: Why High-Performance Work Systems Pay Off. Ithaca, N.Y.: ILR Press (an imprint of Cornell University Press).

Appelbaum, Eileen, and Rosemary Batt. 1994. The New American Workplace. Ithaca, N.Y.: ILR Press (an imprint of Cornell University Press).

Barker, James. 1993. "Tightening the Iron Cage: Concertive Control in Self-Managing Teams." $A d$ ministrative Science Quarterly, Vol. 38, No. 3 (September), pp. 408-37.

Clark, Jon. 1995. Managing Innovation and Change: People, Technology, and Strategy. Thousand Oaks and London: Sage.

Cully, Mark, Stephen Woodland, Andrew O'Reilly, and Gill Dix. 1999. Britain at Work: As Depicted by the 1998 Workplace Employee Relations Survey. London: Routledge.

Daniel, William, and Neil Millward. 1983. Workplace Industrial Relations in Britain. London: Heinemann.

Disney, Richard, Amanda Gosling, and Stephen Machin. 1994. "British Unions in Decline: An Examination of the 1980s Fall in Trade Union Recognition." Industrial and Labor Relations Review, Vol. 48, No. 3 (April), pp. 403-19.

1995. "What Has Happened to Union Recognition in Britain?” Economica, Vol. 63, No. 249, pp. 1-18.

Edwards, Paul K. 1995. "Human Resource Management, Union Voice, and the Use of Discipline: An Analysis of WIRS3." Industrial Relations Journal, Vol. 26, No. 3 (Autumn), 204-20.

Fiorito, Jack. 2001. "Human Resource Management Practices and Worker Desires for Union Representation." Journal of Labor Research, Vol. 22, No. 2 (Spring), pp. 335-54.

Fiorito, Jack, Christopher Lowman, and Forrest D. Nelson. 1997. "The Impact of Human Resource Policies on Union Organizing." Industrial Relations, Vol. 26, No. 1 (Winter), pp. 113-26.

Forth, John, and Neil Millward. 2002. The Growth of Direct Communication. London: Chartered Institute of Personnel and Development.

Godard, John, and John Delaney. 2000. "Reflections on the High-Performance Paradigm's Implications for Industrial Relations as a Field." Industrial and Labor Relations Review, Vol. 53, No. 3 (April), pp. 482-502.

Gospel, Howard, and Paul Willman. 2003. "Dilemmas in Worker Representation: Information, Consultation and Negotiation." In Howard Gospel and Stephen Wood, eds., Representing Workers: Trade Union Recognition and Membership in Modern Britain. London: Routledge, Chapter 8, pp. 144-65.

Guest, David E. 1989. "Human Resource Management: Its Implications for Industrial Relations and Trade Unions." In John Storey, ed., New Perspectives on Human Resource Management. London: Routledge, pp. 41-55.

1995. "Human Resource Management, Trade Unions, and Industrial Relations.” In John Storey, ed., Human Resource Management. London: Routledge, pp. 110-41.

Guest, David, and Neil Conway. 1999. "Peering into the Black Hole: The Downside of the New Employment Relations in the U.K." British Journal of Industrial Relations, Vol. 37, No. 3 (September), pp. 36790.

Hicks, Stephen, and Tom Palmer. 2004. “Trade Union Membership: Estimates from the Autumn 2003 Labour Force Survey." Labour Market Trends, Vol. 112, pp. 99-101.

Kochan, Thomas A. 1980. Collective Bargaining and Industrial Relations. Homewood, Ill.: Richard D. Irwin.

Kochan, Thomas A., Harry C. Katz, and Robert B. McKersie. 1986. The Transformation of American Industrial Relations. New York: Basic Books.

Kochan, Thomas A., and Paul Osterman. 1994. The Mutual Gains Enterprise. Boston: Harvard Business School Press.

Koys, Daniel J. 1991. "Fairness, Legal Compliance, and Organizational Commitment." Employee Responsibilities and Rights Journal, Vol. 4, pp. 283-91.

Machin, Stephen. 2000. "Union Decline in Britain." British Journal of Industrial Relations, Vol. 38, No. 4 (December), pp. 631-45.

2003. "New Workplaces, New Workers: Trade Union Decline and the New Economy." In Howard Gospel and Stephen Wood, eds., Representing Workers: Trade Union Recognition and Membership in Modern Britain. London: Routledge, Chapter 2, pp. 1528.

de Menezes, Lilian, and Stephen Wood. 2005. "Identifying HRM in Britain Using the Workplace Industrial Relations Survey." International Journal of $\mathrm{Hu}$ man Resource Management, forthcoming.

Metcalf, David. 2001. "British Unions: Dissolution or Resurgence Revisited?" In Richard Dickens, Jonathan Wadsworth, and Paul Gregg, eds., The State of Working Britain. London: Centre for Economic Performance, Chapter 4, pp. 25-33.

Millward, Neil, Alex Bryson, and John Forth. 2000. All Change at Work? British Employment Relations, 1980-1998, as Portrayed by the Workplace Industrial Relations Survey Series. London: Routledge.

Millward, Neil, and Mark Stevens. 1986. British Workplace Industrial Relations, 1980-84. Aldershot: Gower.

Millward, Neil, Mark Stevens, David Smart, and W. R. Hawes. 1992. Workplace Industrial Relations in Transition. Aldershot: Dartmouth Publishing.

Millward, Neil, Stephen Woodland, Alex Bryson, John Forth, and Simon Kirby. 2002. "A Bibliography of Research Based on the British Workplace Industrial Relations Survey Series." September 2002 version available at http://www.niesr.ac.uk/niesr/wers98/ BIBLIOGR.HTM.

Ng, Ignace, and Dennis Maki. 1994. "Trade Union Influence on Human Resource Management Practices. Industrial Relations." Industrial Relations, Vol. 33, No. 1 (January), 121-35. 
Pencavel, John. 2004. "The Surprising Retreat of Union Britain." In Richard Blundell, David Card, and Richard Freeman, eds., Seeking a Premier League Economy. New York: National Bureau of Economic Research, pp. 181-232.

Price, Robert, and George Sayers Bain. 1983. "Union Growth in Britain: Retrospect and Prospect." British Journal of Industrial Relations, Vol. 21, No. 1 (March), pp. 46-68.

Rubinstein, Saul A., and Thomas A. Kochan. Learning from Saturn. Ithaca, N.Y.: ILR Press (an imprint of Cornell University Press).

Scott, Andrew. 1994. Willing Slaves? Cambridge: Cambridge University Press.

Sisson, Keith. 1993. "In Search of HRM." British Journal of Industrial Relations, Vol. 31, No. 2 (June), pp. 201-11.

Starkey, Ken, and Alan McKinlay. 1993. Strategy and the Human Resource. Oxford: Blackwell.

Storey, John. 1992. Developments in the Management of Human Resources. Oxford: Blackwell.

Verma, Anil, Thomas A. Kochan, and Stephen J. Wood. 2002. "Union Decline and Prospects for Revival: Editors' Introduction." British Journal of Industrial Relations, Vol. 40, No. 3 (September), pp. 373-84.

Waddington, Jeremy. 1992. "Trade Union Membership in Britain, 1980-87: Unemployment and Restructuring." British Journal of Industrial Relations, Vol. 30, No. 2 (June), pp. 287-324.

Weitbrecht, Hansjörg. 2003. "Human Resource Management and Co-Determination." In Walter Muller-Jentsch and Hansjörg Weitbrecht, The Changing Contours of German Industrial Relations. Muchen and Mering: Rainer Hampp Verlag, pp. 57-79.

Wickens, Peter. 1987. The Road to Nissan. Houndsmill: MacMillan.

Wood, Stephen. 1996. "High Commitment Management and Unionization in the U.K." International Journal of Human Resource Management, Vol. 7, No. 1 (March), pp. 41-58.

1999. "Getting the Measure of the Transformed Organization." British Journal of Industrial Relations, Vol. 37, No. 3 (September), pp. 391-419. Wood, Stephen, and Maria Teresa Albanese. 1995. "Can We Speak of High Commitment Management on the Shop Floor?" Journal of Management Studies, Vol. 32, No. 2 (March), pp. 215-47.

Wood, Stephen, and Lilian De Menezes. 1998. "High Commitment Management in the U.K.: Evidence from the Workplace Industrial Relations Survey, and Employers' Manpower and Skills Practices Survey." Human Relations, Vol. 51, No. 4 (April), pp. 485-515.

Wood, Stephen, Lilian de Menezes, and Ana Lasaosa. 2003. "Family Friendly Management in Great Britain: Testing Various Perspectives." Industrial Relations, Vol. 42, No. 2 (Spring), pp. 221-50.

Wood, Stephen, C. B. Stride, Toby D. Wall, and Chris W. Clegg. 2004. "Revisiting the Use and Effectiveness of Modern Management Practices." Human Factors and Ergonomics in Manufacturing, Vol. 14, No. 4, pp. 415-32.

Wood, Stephen, and Toby Wall. 2002. "Human Resource Management and Business Performance." In Peter Warr, ed., The Psychology of Work. Harmondsworth: Penguin, Chapter 14, pp. 351-74. 